\title{
Orudis in Management of Rheumatoid Arthritis and Osteoarthrosis of the Hip: Comparison with Indomethacin
}

\author{
A. N. GYORY, M. BLOCH, H. C. BURRY, R. GRAHAME
}

British Medical fournal, 1972, 4, 398-400

\section{Summary}

In double-blind cross-over studies in 46 patients with rheumatoid arthritis and in 42 patients with osteoarthrosis of the hip, Orudis-a new non-steroidal antiinflammatory agent-has been shown to be well tolerated and to have comparable therapeutic efficacy with indomethacin when given in equal dosage. Side effects were less severe with Orudis. The results suggest that Orudis will prove valuable in the clinical management of rheumatic diseases.

\section{Introduction}

A major problem in the management of inflammatory and degenerative arthritis has been to find an anti-inflammatory analgesic drug which combines potency with safety. Thus the well-established agents in current use, including salicylates, corticosteroids, phenylbutazone, and indomethacin, have ulcerogenic properties as well as other serious toxic or side effects, while the efficacy of other, safer drugs such as ibuprofen has been questioned (Hart, 1972; Owen-Smith and Burry, 1972). Orudis, 2-(3-benzoylphenyl) propionic acid, is well tolerated by patients and has a very low incidence of side effects and toxic reactions (Cathcart et al., 1972; Gomez, 1972; Mason et al., 1972); in particular, overt gastrointestinal bleeding has not been reported. Laboratory studies have shown its potency as an anti-inflammatory agent in animals (Julou et al., 1971), and recent double-blind cross-over studies against placebo have shown it to have great potency in man (Cathcart et al., 1972; Mason et al., 1972). The current studies were designed to compare Orudis with an established non-steroidal anti-imflammatory agent, indomethacin, in the management of rheumatoid arthritis and osteoarthrosis of the hip.

\section{Method}

Study 1 comprised 50 patients with classical or definite rheumatoid arthritis, as defined by the American Rheumatism Association criteria (Ropes et al., 1959), who had not received systemic or intra-articular corticosteroid therapy, gold, or immunosuppressive therapy during the four weeks preceding the trial.

Study 2 comprised 44 patients with osteoarthrosis of the hip, the diagnosis satisfying the following criteria: (1) pain and limitation of range of movement in one or both hip joints, and (2) at least three out of four radiological features of osteoarthritis in one or both hip joints-(a) narrowing of joint space, $(b)$ subchondral sclerosis, $(c)$ osteophytosis, $(d)$ deformity of the femoral head. Patients with protrusioacetabulae, gout, Paget's disease, or rheumatoid arthritis were excluded.

Children, women of child-bearing age in whom the possibility of pregnancy could not be excluded, patients with gastro-

Department of Rheumatology, Guy's Hospital, London S.E.1

A. N. GYORY, B.SC., M.R.C.P., Honorary Senior Registrar (Present address: Mayo Clinic, Rochester, Minnesota, U.S.A.)

H. C. BURRY, M.R.C.P., M.R.A.C.P., Consultant Rheumatologist

R. GRAHAME, M.D., M.R.C.P., Consultant Rheumatologist

May Baker Ltd., Dagenham, Essex

M. BLOCH, M.D., Medical Adviser intestinal or liver disease, and patients known to be intolerant of indomethacin were excluded from participation in both sections of the trial.

A double-blind cross-over technique was used, patients receiving two weeks' treatment with each trial drug in turn, the sequence being determined by random allocation. Drugs were supplied in capsules of identical appearance containing $25 \mathrm{mg}$ of active agent, one capsule being taken four times daily with meals. Patients were given a measured supply of paracetamol tablets $(0.5 \mathrm{~g})$ to be used only for control of severe pain. All other antirheumatic and analgesic therapy was stopped at the time of the initial assessment.

All assessments were made by the same observer at the start of the trial, at two weeks, and again at four weeks, according to the following criteria.

Study 1.-Subjective assessments were based on answers to agreed standard questions. Severity of pain (nil, slight, moderate, severe, very severe), functional grading (modified after Steinbrocker et al. (1949), grade II being subdivided into two categories of severity of disability), global assessment of current clinical state (very poor, poor, fair, good, very good), and comparative global assessment (much worse, worse, unchanged, better, much better) were scored on a five-point scale grading severity of disease from 0 to 4 . Duration of morning stiffness (more than 3 hours, 1-3 hours, less than 1 hour, nil) was based on a 0 to 3 scale. At the end of the trial patients were asked to state a preference for the treatment given. Objective assessments were of grip strength (based on the mean of three measurements obtained from each hand with the bag inflated to $30 \mathrm{~mm} \mathrm{Hg}$ ), articular index (Ritchie et al., 1968), and joint size (Boardman and Hart, 1967). The number of paracetamol tablets used (rescue-drug count) provided an indication of the relative efficacy of study and reference drugs in suppressing pain.

Study 2.-Subjective assessments were based on answers to agreed questions. Severity of overall pain, night pain, and morning pain, functional grading, global assessment of current clinical state, and comparative global assessment were based on a five-point scale as for study 1 , and, similarly, patients were asked to state a preference for one of the two treatments given. Objective assessments were of intermalleolar straddle and intercondylar distance (Owen-Smith and Burry, 1972), and were recorded as the mean of measurements taken when first pain started and at maximum displacement tolerated by the patient. The rescue-drug count, as with study 1 , provided an indirect objective assessment.

In both studies all medicine containers were returned at the end of each treatment period, any remaining capsules and tablets were counted, and the number taken during the trial was calculated.

Side effects were noted at each assessment in response to the questions: Has the treatment upset you in any way during the past two weeks? If yes, in what way?

Laboratory investigations undertaken at each assessment were: full blood count, E.S.R. (Westergren), plasma alkaline phosphatase, bilirubin, urea, aspartate transferase, serum hydroxybutyric dehydrogenase, and urine analysis.

\section{Results}

Forty-six patients with rheumatoid arthritis completed the trial (Table I). Of the four patients excluded from the analysis two developed exacerbation of symptoms, one during the Orudis 
treatment and the other when on indomethacin, and two were withdrawn after administrative errors. Side effects were experienced by 22 patients-in 4 cases only when on Orudis, in 5 only when on indomethacin, and in 12 when on both drugs. The results are summarized in Tables II and III.

Of the patients with osteoarthrosis 42 completed the trial (Table IV). Two others were excluded-one developed exacerbation of symptoms during treatment with Orudis and one took aspirin in addition to the trial drug and paracetamol. Altogether 15 patients had side effects- 3 only when on Orudis, 7 only when on indomethacin, and 5 when on both drugs. The results are summarized in Tables $\mathrm{V}$ and VI.

TABLE I-Details of the 46 Patients with Rheumatoid Arthritis who Completed the Trial

\begin{tabular}{|c|c|c|c|c|c|c|c|c|}
\hline \multirow[t]{2}{*}{$\begin{array}{l}\text { Trial Drug } \\
\text { Sequence }\end{array}$} & \multicolumn{3}{|c|}{$\begin{array}{l}\text { No. of } \\
\text { Patients }\end{array}$} & \multicolumn{2}{|c|}{$\begin{array}{c}\text { Age } \\
\text { (Years) }\end{array}$} & \multicolumn{3}{|c|}{$\begin{array}{l}\text { Duration of } \\
\text { Illness } \\
\text { (Years) }\end{array}$} \\
\hline & M. & F. & Total & Range & Mean & $<1$ & $1-5$ & $>5$ \\
\hline $\begin{array}{l}\text { Indomethacin/ } \\
\text { Orudis } \\
\text { Orudis/ }\end{array}$ & $\begin{array}{r}10 \\
8\end{array}$ & $\begin{array}{l}12 \\
16\end{array}$ & $\begin{array}{l}22 \\
24\end{array}$ & $\begin{array}{l}34-74 \\
32-71\end{array}$ & $\begin{array}{l}56 \\
58\end{array}$ & $\begin{array}{l}0 \\
0\end{array}$ & 9 & $\begin{array}{l}13 \\
13\end{array}$ \\
\hline
\end{tabular}

TABLE II-Drug Preference and Subjective Assessment of Condition among the 46 Patients with Rheumatoid Arthritis Completing Trial

\begin{tabular}{|c|c|c|c|c|}
\hline & $\begin{array}{c}\text { No } \\
\text { Improve- } \\
\text { ment or } \\
\text { Drug } \\
\text { Preference }\end{array}$ & \begin{tabular}{|c} 
Patients \\
Preferring \\
Orudis
\end{tabular} & $\begin{array}{l}\text { Patients } \\
\text { Preferring } \\
\text { Indo-- } \\
\text { methacin }\end{array}$ & $\begin{array}{c}\mathbf{P} \\
\text { Value }\end{array}$ \\
\hline $\begin{array}{ll}\text { Pain } & \ldots \\
\text { Duration of morning stiffness } & \ldots \\
\text { Current clinical state } & \ldots \\
\text { Comparative clinical state } & \ldots \\
\text { Functional dependency } & \ldots \\
\text { Overall drug preference } & \ldots\end{array}$ & $\begin{array}{r}27 \\
27 \\
22 \\
13 \\
26 \\
5\end{array}$ & $\begin{array}{r}8 \\
7 \\
11 \\
14 \\
8 \\
23\end{array}$ & $\begin{array}{l}11 \\
12 \\
13 \\
19 \\
12 \\
18\end{array}$ & $\begin{array}{l}\text { N.S. }(0 \cdot 65) \\
\text { N.S. }(0.36) \\
\text { N.S. }(0.84) \\
\text { N.S. }(0 \cdot 49) \\
\text { N.S. }(0.50) \\
\text { N.S. }(0.63)\end{array}$ \\
\hline
\end{tabular}

N.S. $=$ Not significant.

TABLE III-Observer Assessment of Results in the 46 Patients with Rheumatoid Arthritis according to Subjective Drug Preference. Mean Values given

\begin{tabular}{|c|c|c|c|c|}
\hline & & \multicolumn{2}{|c|}{ Preferred Drug } & \multirow{2}{*}{$\underset{\text { Value }}{\mathbf{P}}$} \\
\hline & & Orudis & Indomethacin & \\
\hline $\begin{array}{l}\text { Total grip strength of both hand } \\
\text { (mm Hg) } \\
\begin{array}{l}\text { Articular index } \\
\text { Joint size }\end{array} \\
\begin{array}{l}\text { Rescue-drug count } \\
\text { (No. taken) }\end{array}\end{array}$ & $\begin{array}{l}\because \\
\ddot{*}\end{array}$ & $\begin{array}{r}318 \\
18 \cdot 01 \\
589 \\
40\end{array}$ & $\begin{array}{r}319 \\
16 \cdot 51 \\
588 \\
34\end{array}$ & $\begin{array}{l}\text { N.S. }(0 \cdot 80) \\
\text { N.S. }(0 \cdot 30) \\
\text { N.S. }(0 \cdot 50) \\
\quad<0 \cdot 05\end{array}$ \\
\hline
\end{tabular}

N.S. = Not significant.

TABL. v-Drug Preference and Subjective Assessment of Condition Among the 42 Patients with Osteoarthrosis Completing Trial

\begin{tabular}{|c|c|c|c|c|c|}
\hline . & & \begin{tabular}{|c|} 
No \\
Improve- \\
ment or \\
Drug \\
Preference
\end{tabular} & \begin{tabular}{|c} 
Patients \\
Preferring \\
Orudis
\end{tabular} & $\begin{array}{c}\text { Patients } \\
\text { Preferring } \\
\text { Indo- } \\
\text { methacin }\end{array}$ & $\begin{array}{c}\mathbf{P} \\
\text { Value }\end{array}$ \\
\hline $\begin{array}{lll}\text { Overall pain } & \ldots & \ldots \\
\text { Night pain } & \ldots & \ldots \\
\text { Morning pain } & \ldots \\
\text { Current clinical state } & \ldots \\
\text { Comparative clinical state } \\
\text { Functional dependency } \\
\text { Overall drug preference }\end{array}$ & $\begin{array}{l}\because \\
\because \\
\because \\
\ddot{ } \\
\therefore\end{array}$ & $\begin{array}{r}19 \\
17 \\
13 \\
15 \\
13 \\
29 \\
6\end{array}$ & $\begin{array}{r}8 \\
12 \\
12 \\
12 \\
10 \\
2 \\
17\end{array}$ & $\begin{array}{l}15 \\
13 \\
17 \\
15 \\
19 \\
11 \\
19\end{array}$ & $\begin{array}{l}\text { N.S. }(0 \cdot 21) \\
\text { N.S. }(1 \cdot 00) \\
\text { N.S. }(0 \cdot 35) \\
\text { N.S. }(0 \cdot 7) \\
\text { N.S. }(0.14) \\
<0.004 \\
\text { N.S. }\end{array}$ \\
\hline
\end{tabular}

N.S. = Not significant.
TABLE VI-Observer Assessment of Results in the 42 Patients with Osteoarthrosis according to Subjective Drug Preference. Mean Values given

\begin{tabular}{|c|c|c|c|c|}
\hline \multirow[b]{3}{*}{$\begin{array}{l}\text { Intermalleolar straddle } \\
\text { Intercondylar distance } \\
\text { Rescue-drug count (No. taken) }\end{array}$} & \multirow[b]{3}{*}{$\begin{array}{l}. \\
\ldots\end{array}$} & \multicolumn{2}{|c|}{ Preferred Drug } & \multirow{3}{*}{$\begin{array}{c}\text { P Value } \\
\text { N.S. } \\
\text { N.S. } \\
\text { N.S. }\end{array}$} \\
\hline & & Orudis & Indomethacin & \\
\hline & & $\begin{array}{r}133 \\
83 \\
30\end{array}$ & $\begin{array}{r}134 \\
84 \\
28\end{array}$ & \\
\hline
\end{tabular}

N.S. = Not significant.

Results from the two trials showed that there was little difference between the two drugs, the only variables-out of 20 investigated-in which differences reached statistically significant proportions were in respect of the number of paracetamol tablets taken for pain relief in the rheumatoid arthritis trial $(P<0.05)$ and the changes in functional dependency in the osteoarthrosis trial $(P<0.004)$. Both these results favoured indomethacin. Significant improvement in functional dependency was seen only in the group starting treatment with indomethacin, and was absent in the group taking the drugs in the reverse order. Since the two treatment groups were not well matched with regard to functional dependency, in that the group taking indomethacin first contained fewer patients in the more severely incapacitated grades, it seems likely that the result was related to this disparity.

Despite the fact that patients known to be intolerant of indomethacin were excluded from the trial side effects were more frequent with indomethacin and tended to be more severe, particularly with regard to symptoms referable to the central nervous system (Table VII). In no case, however, were they sufficiently severe to warrant stopping treatment.

Biological Monitoring.-In a number of instances with either drug the serum hydroxybutyric dehydrogenase concentration became increased above the normal range. These changes were not associated with change in bilirubin, alkaline phosphatase, or aspartate transferase concentration, and probably were not significant. Significant changes did not occur elsewhere. TABLE vII-Incidence of Symptoms Developing in 94 Patients* Admitted to
Rheumatoid Arthritis and Osteoarthrosis Studies

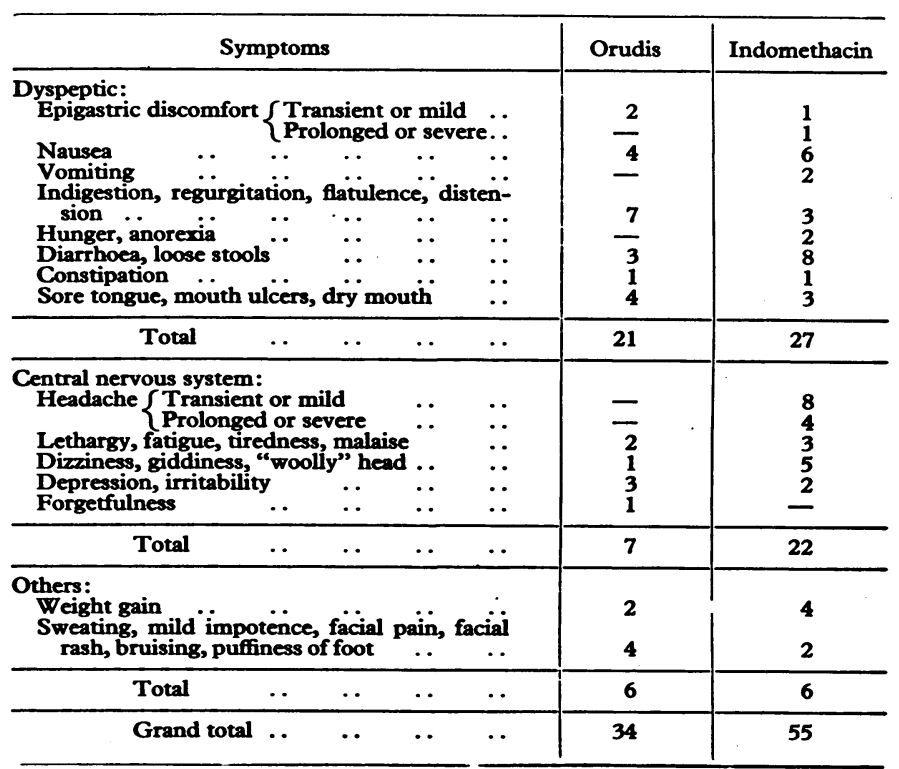

*Including patients withdrawn from the trials.

Symptoms were absent in 51 patients.

TABLE IV-Details of the 42 Patients with Osteoarthrosis who Completed the Trial

\begin{tabular}{|c|c|c|c|c|c|c|c|c|c|c|}
\hline \multirow{2}{*}{$\begin{array}{l}\text { Trial Drug } \\
\text { Sequence }\end{array}$} & \multicolumn{3}{|c|}{ No. of Patients } & \multicolumn{2}{|c|}{ Age (Years) } & \multirow{2}{*}{$\begin{array}{l}\text { No. with Both } \\
\text { Hips } \\
\text { Involved }\end{array}$} & \multirow{2}{*}{$\begin{array}{l}\text { No. with One } \\
\text { Hip } \\
\text { Involved }\end{array}$} & \multicolumn{3}{|c|}{ Duration of Illness (Years) } \\
\hline & M. & F. & Total & Range & Mean & & & $<1$ & $1-5$ & $>5$ \\
\hline $\begin{array}{l}\text { Indomethacin/Orudis } \\
\text { Orudis/indomethacin }\end{array}$ & $\begin{array}{l}10 \\
10\end{array}$ & 12 & 22 & $\begin{array}{l}42-81 \\
30-80\end{array}$ & 64 & $\begin{array}{l}17 \\
12\end{array}$ & $\begin{array}{l}5 \\
8\end{array}$ & 1 & $\begin{array}{l}14 \\
14\end{array}$ & $\begin{array}{l}7 \\
6\end{array}$ \\
\hline
\end{tabular}




\section{Discussion}

Studies conducted elsewhere in the United Kingdom (Cathcart et al., 1972; Gomez, 1972; Mason et al., 1972) have indicated that in the dosage used in the present study Orudis is well tolerated, causes only occasional and minor side effects, and has statistically significant superiority $(P<0.01)$ in antiinflammatory and analgesic activity when compared with placebo.

Indomethacin is a powerful anti-inflammatory and analgesic drug (Percy et al., 1964; Hart and Boardman, 1965; Thompson and Percy, 1966), its principal disadvantage being a relatively high incidence of side effects.

The present studies suggest that in equal dosage clinical efficacy of Orudis is comparable with that of indomethacin. The results marginally favour the latter drug but side effects were less severe with the former. Preliminary results from studies with higher dosages of Orudis (Gomez, 1972; Mason et al., 1972) indicate that $150 \mathrm{mg}$ daily is well tolerated. This finding considered together with the above results suggests that Orudis is likely to have an important part to play in the clinical management of rheumatic disease.
We are indebted to Miss Ilse Tauber, of May \& Baker Ltd., for the statistical analysis, and to May \& Baker Ltd. for the drugs and record cards used in the two trials.

\section{References}

Boardman, P. L., and Hart, F. D. (1967). British Medical fournal, 4, 264. Cathcart, B. J., Vince, J. D., Gordon, A. J., Bell, M. A., and Chalmers, I. M. (1972). In press.

Gomez, G. (1972). Personal communication.

Gomez, G. (1972). Personal communication

Hart, F. D., and Boardman, P. L. (1965). British Medical fournal, 2, 1281.

Julou, L., et al. (1971). Fournal de Pharmacologie, 2, 3, 259.

Mason, R. M., Zutshi, D. W., Marr, S., and Bloch, M. (1972). Personal communication.

Owen-Smith, B. D., and Burry, H. C. (1972). Rheumatology and Physical Medicine, $2,281$.

Percy, J. S., Stephenson, P., and Thompson, M. (1964). Annals of Rheumatic Diseases, 23, 226.

Ritchie, D. M., et al. (1968). Quarterly fournal of Medicine, 37, 393.

Ropes, M. W., Bennett, G. A., Cobb, S., Jacox, R., and Jessar, R. (1959). Annals of Rheumatic Diseases, 18, 49.

Steinbrocker, O., Traeger, C. H., and Batterman, R. C. (1949). Fournal of the American Medical Association, 140, 659.

Thompson, M., and Percy, J. S. (1966). British Medical fournal, 1, 80.

\title{
Hypercalcaemia, Hypophosphataemia, and Inability to Excrete Hydrogen Ions
}

\author{
HERIBERTO ARCILA, JOSÉ CHÁVEZ DE LOS RÍOS, RODOLFO VAN DYCK, \\ EDUARDO ZORRILLA
}

British Medical fournal, 1972, 4, 400-403

\section{Summary}

Investigation of a patient with hypercalcaemia, hypophosphataemia, and nephrocalcinosis failed to lead to a clear diagnosis. Neither primary hyperparathyroidism nor primary incomplete renal tubular acidosis could explain all the biochemical features, and it seems that more than one fundamental abnormality may have been present.

\section{Introduction}

Biochemical changes produced by excessive parathyroid hormone and their effects on several organs and tissues are well known. Hypercalcaemia, hypophosphataemia, and nephrocalcinosis are common in advanced cases, and inability to eliminate hydrogen ions in the urine has been reported in a number of patients (Fourman et al., 1960).

The case of a patient with all these conditions is reported here in whom a diagnosis of primary hyperparathyroidism was rejected on the basis of suppressed serum parathyroid hormone levels and normal response to parathyroid extract infusion (Becker et al., 1964), prednisone administration (Thomas et al., 1958), and intravenous calcium infusion (Goldsmith and Forland, 1964).

\footnotetext{
Instituto Nacional de Cardiologia, Mexico

HERIBERTO ARCILA, M.D., Research Assistant, Department of Nephrology

RODOLFO VAN DYCK, M.D., Fellow, Department of Nephrology

EDUARDO ZORRILLA, M.D., Research Assistant, Department of Endocrinology

Metabolic Unit, Hospital de la Raza, Instituto Mexicano del Seguro Social, Mexico

JOSÉ CHÁVEZ DE LOS RÍOS, M.D., Assistant Professor of Medicine
}

This patient's disorder, while similar to the late type of incomplete renal tubular acidosis (Elkinton et al., 1960), was associated with hypercalcaemia, which has not been reported previously in that syndrome.

\section{Case Report}

An 18-year-old man was admitted to the Instituto Nacional de Cardiologia for investigation of nephrocalcinosis. He had been well until six months previously, when he complained of dysuria and polyuria. His physician found a urinary infection and prescribed antibiotics. Nephrocalcinosis, hypercalcaemia, and hypophosphataemia were also discovered and the patient was referred to this Institute. There was no family history of renal disease but his father has essential hypertension. Physical examination showed nothing abnormal. His weight was $68 \mathrm{~kg}$, height $178 \mathrm{~cm}$, body surface area $1.82 \mathrm{~m}^{2}$, blood pressure $120 / 80 \mathrm{~mm} \mathrm{Hg}$, heart rate $88 / \mathrm{min}$, and ventilatory rate $18 / \mathrm{min}$.

Serum calcium was high in numerous determinations, with levels varying from 11.0 to $12.0 \mathrm{mg} / 100 \mathrm{ml}$, while the serum phosphorus was low, with values ranging from 1.4 to $2.7 \mathrm{mg} / 100 \mathrm{ml}$. Alkaline phosphatase was 3.6 Bodansky units. Blood urea nitrogen was $42 \mathrm{mg} / 100 \mathrm{ml}$, and serum creatinine $1.0 \mathrm{mg} / 100 \mathrm{ml}$. Maximum tubular reabsorption of glucose was $191 \mathrm{mg} / \mathrm{min}$, and maximum tubular secretion of para-aminohippurate (PAH) $56 \mathrm{mg} / \mathrm{min}$. Glomerular filtration rate was $77 \mathrm{ml} / \mathrm{min}$ (inulin clearance), and renal plasma flow $286 \mathrm{ml} / \mathrm{min}$ (PAH clearance). Serum albumin was $4.55 \mathrm{~g} / 100 \mathrm{ml}$, and globulins were $2.68 \mathrm{~g} / 100 \mathrm{ml}$. Paper electrophoresis showed normal plasma proteins. Total serum carbon dioxide was $26 \mathrm{mEq} / \mathrm{l}$, and $\mathrm{pH}$ was $7 \cdot 42$. Haemoglobin was 15.6 $\mathrm{g} / 100 \mathrm{ml}$, and the haematocrit reading $49 \%$. Leucocyte count was $7,400 / \mathrm{mm}^{3}$. Urine analysis showed low densities from 1004 to 1014. Urinary $\mathrm{pH}$ ranged from 6 to 7. Several urine cultures were negative.

A shortening of the S-T interval was present on the electrocardiogram. $X$-ray films of the chest, long bones, hands. feet, skull, and teeth showed no bone lesions. An intravenous pyelogram confirmed bilateral renal calcifications distributed diffusely on the parenchyma (Fig. 1) without alterations in the ureters or bladder. 